\title{
Taking Identity Seriously: When Identity Meets Regulation ${ }^{1}$
}

\author{
Pre-print version \\ Published in Journal of Financial Regulation (2016) 2(2): 182-202
}

DOI: $\underline{10.1093 / \mathrm{jfr} / \mathrm{fjw} 008}$

\begin{abstract}
Financial stability is a public good. Banking regulation has a vital role to play in the provision and maintenance of financial stability. This article introduces a multiple identity approach to the regulation of the banking sector. It conceptualises bankers and regulators sharing a common social identity with the rest of the society, namely taxpayer identity besides their respective banker and regulator identities. The article underlines the balance between two social identities, and the reasons why bankers and regulators cannot achieve a balance between the two. Finally, motivated by the multiple identity approach on the political economy of banking regulation, the article discusses two major policy recommendations for regulatory design, at least, to partially address the multiple identity problem.
\end{abstract}

KEYWORDS: financial regulation, identity, political economy of regulation, bankers and regulators, bail-in, bail-out

\section{INTRODUCTION}

Financial stability ${ }^{2}$ is a public good. ${ }^{3}$ As it is difficult to restrict individuals from enjoying it, its consumption also does not reduce the amount available to others. As with any public good, financial stability can be over-consumed. Thus, the result is a financial debacle à la the tragedy of the commons and Minsky's financial instability hypothesis. ${ }^{4}$ Once more, the recent global financial crisis has reminded us that the financial and banking sectors are inherently

\footnotetext{
${ }^{1}$ This article is a revised and updated version of paper presented at the International Workshop on Institutional and Policy Design in Financial Sector Reform in Istanbul on September 25-26, 2015. I wish to thank Michael Howlett, M Ramesh, Caner Bakir, and JJ Woo, and the participants particularly Katalin Mero, W. Trevis Selmier II, and Kevin Young for their constructive comments on the previous version of this article. Yvonne Guo's constructive comments and assistance improved the quality of the article. More importantly, I thank Ramkishen S. Rajan, Razeen Sally, and Kurtulus Gemici for encouraging me to work on this demanding task to think more deeply about the article and bring different literatures together. Finally, I thank the two anonymous referees for their constructive comments and suggestions. All remaining mistakes are mine.

${ }^{2}$ I define financial stability as non-existence of a major systemic banking, balance of payment, currency, sovereign debt crises in a given year. The definitions of these crises, except systemic banking crisis, are available in A Kose and S Claessens, 'Financial Crises: Explanations, Types, and Implications' International Monetary Fund Working Paper 13/28, 30 January 2013. The authors focus only on bank runs to explain banking crises although there might be other causes of banking crises. For a discussion see A Demirgüç-Kunt and E Detragiache, 'The Determinants of Banking Crises in Developing and Developed Countries' (1998) 45 IMF Staff Articles 81.

${ }^{3}$ See P A Samuelson, 'The Pure Theory of Public Expenditure' (1954) 36 The Review of Economics and Statistics 387-389. Samuelson made a distinction between private consumption goods and collective consumption goods. The latter is what we are calling public good in today's terminology. He defined collective consumption goods as "[a]ll [individuals] enjoy in common in the sense that each individual's consumption of such a good leads to no substraction from any other individual's consumption of that good..."(ibid, 387). As a result, we can assume that financial stability is a public good because consumers of stability can hardly be excluded from benefitting from it. And, its consumption does not reduce the available remainder for others to consume it.

${ }^{4}$ G Hardin, 'The Tragedy of the Commons' (1968) 162 Science 1243; H P Minsky, Stabilizing an Unstable Economy, Foreword with Henry Kaufman (McGraw Hill 2008[1986]).
} 
unstable. This had been convincingly noted previously by Keynes, Kindleberger, Minsky, and recently by Reinhart and Rogoff..$^{5}$

When such instabilities arise, banks and other financial intermediaries produce negative and contagious externalities not only in jurisdictions they are based in, but also in others due to the interdependent and complex nature of modern finance and banking. Due to the special roles of banks and non-bank financial intermediaries, government regulation ${ }^{6}$ has existential value as long as the direct fiscal costs financial and banking crises produce are considered. ${ }^{7}$ Alongside fiscal costs, crises also lead to dramatic output losses that may easily translate into higher levels of unemployment, and other socio-economic challenges.

This article, motivated by the economic theory of identity, argues that a multiple identity approach $^{8}$ and revisits an on-going debate on the political economy of banking regulation, focusing on the role of the multiple identities (i.e. multiple social roles) bankers and regulators have. In doing so, it aims to provide insights about the design of the regulatory frameworks. The article acknowledges that the current policy-oriented debate on the design of regulatory frameworks mainly concentrates on banker and/or regulator identity. The reason of that observation is that corporate governance, ${ }^{9}$ the primacy of political institutions and property rights, ${ }^{10}$ and prudential regulation, ${ }^{11}$ and macroeconomic policy ${ }^{12}$ approaches seem to be single identity-oriented. More importantly, the conception of taxpayer versus banker is too reductionist and totally lacks an understanding of real-life challenges both bankers and policymakers have to grapple with.

From a multiple identity approach, this article argues that a particular behaviour, for instance being prudent or not in the case of bankers, or being captured or having a public-interest orientation in the case regulators, might be somewhat rational according to one identity, but that behaviour might not be rational according to another identity. In the interest of parsimony, this article focuses only on two identities bankers and regulators have. Both regulators and bankers are taxpayers. In the meantime, they have their own respective identities, viz. banker and regulator. This article introduces another identity into the analysis

\footnotetext{
${ }^{5} \mathrm{~J}$ M Keynes, The General Theory of Employment, Interest and Money (Harvest/Harcourt Inc. 1965[1936]); C P Kindleberger, Manias, Panics, Crashes: A History of Financial Crises (Basic Books 1978); H P Minsky, Stabilizing an Unstable Economy (Foreword with Henry Kaufman, McGraw Hill 2008[1986]); C Reinhart and K Rogoff, This is Times is Different: Eight Centuries of Financial Folly (Princeton UP 2009).

${ }^{6}$ Regulation here is defined following B M Mitnick, The Political Economy of Regulation: Creating, Designing, and Removing Regulatory Forms (Columbia UP 1980). Mitnick highlights various definitions of regulation. The broadest definition the author presents is as follows: "regulation is the intentional restriction of a subject's choice of activity, by an entity not directly part to or involved in that activity" (ibid, 5).

${ }^{7}$ D Amaglobeli and others, 'From Systemic Banking Crises to Fiscal Costs', International Monetary Fund Working Paper 15/166. 20 July 2015; L Laeven and F Valencia, 'Systemic Banking Crises Database' (2013) 61 IMF Economic Review 225.

${ }^{8}$ G A Akerlof and R E Kranton, 'Economics and Identity' (2000) 115 The Quarterly Journal of Economics 715; G A Akerlof and R E Kranton, Identity Economics: How Our Identities Shape Our Work, Wages, and Well-being (Princeton UP 2010); A Sen, Identity and Violence: The Illusion of Destiny (W.W. Norton\& Co 2006); J B Davis, Individuals and Identity in Economics (Cambridge UP 2011).

${ }^{9}$ L Laeven and R Levine, 'Bank Governance, Regulation, and Risk-Taking' (2009) 93 J Financial Economics 259; L Laeven, 'Corporate Governance: What's Special about Banks?' (2013) 5 Annual Review of Financial Economics 63.

${ }^{10} \mathrm{C}$ W Calomiris and S H Haber, Fragile by Design: The Political Origins of Banking Crises and Scarce Credit (Princeton UP 2014).

${ }^{11}$ M Dewatripont, J Rochet, and J Tirole, Balancing Banks: Global Lessons from the Global Financial Crisis (Keith Tribe tr, Princeton UP 2010).

${ }^{12}$ G Akerlof and others, What Have We Learned? Macroecomic Policy after the Crisis (MIT Press 2014).
} 
and argues that we also need to allow other identities such as taxpayer identity and acknowledge their effect during the design phase of a regulatory framework. The article briefly discusses two potential adjustments in the regulatory design to at least partially address the gap between two identities both bankers and regulators to boost the ownership of and accountability of bankers and regulators with respect to financial stability.

The article is divided into three main sections. The first section briefly reviews the literature on riskiness in the banking sector, drivers of (systemic) banking crises, and the incentives a banker has according to given institutional and structural factors. The second section concentrates on the multiple identity problem and its implications on banking regulation. The third section reviews the political economy of (banking) regulation in light of the multiple identities approach. The last section ends with a brief discussion of policy recommendations.

\section{BANKS, RISKINESS, AND REGULATORSIN THE LITERATURE}

\section{(a) Banks, Bankers, and Riskiness}

The emergence of banks in the modern economy has evolved with their influential role in the economy. ${ }^{13}$ They act as intermediaries between the State, the public, international borrowers and lenders, and other domestic and foreign actors in a given context. In the modern economy, banks have a special role, and the regulation of the banking system has a lifebearing importance for the whole economy and society as banks are serving multiple constituencies. ${ }^{14}$ Banks are serving various shareholders and stakeholders at the same time, and are engaging in complex and multifaceted tasks. One of the main roles they play is to reduce the transaction costs of information gathering and monitoring on behalf of creditors. ${ }^{15}$ Additionally, they intermediate between savings and credit allocation which may for instance lead to the development of the overall economy. ${ }^{16}$ Also, banks facilitate settlements of payments among individuals, firms, and nations.

Their unique role also arises due to maturity transformation. Banks borrow liquid short-term funds, but lend for risky, opaque, and long-term investments. Banks are special when they fail as well. Instability in the interbank money market due to an individual failure in the banking sector could easily become contagious with substantial negative externalities to other banks because they lend and borrow from each other in the interbank money market. ${ }^{17}$

While banks have special roles in serving the society as an intermediary between savers and borrowers, and are unique in the case of failure due to their potential of having spill-over effects on a particular sector and/or the whole economy, it is also hard to monitor banks for several reasons. For instance, deposit insurance, which is designed to protect depositors - the

\footnotetext{
${ }^{13}$ See for an historical account of the rise and role of banks in emergence of the modern economy, C Tilly, Coercion, Capital, and European States, AD990-1992 (Basil Blackwell 1990); N Ferguson, The Ascent of Money: A Financial History of the World (Penguin Press 2008); R S Grossman, The Unsettled Account: The Evolution of Banking in the Industrialised World Since 1800 (Princeton UP 2010); D Stasavage, States of Credit: Size, Power, and the Development of European Polities (Princeton UP 2011).

${ }^{14}$ M Becht, P Bolton, and A Röell, 'Why Bank Governance is Different' (2011) 27 Oxford Review of Economic Policy 437.

${ }^{15}$ D W Diamond, 'Financial Intermediation and Delegated Monitoring' (1984) 51 Review of Economic Studies 393.

16 J A Schumpeter, The Theory of Economic Development (Transaction Publishers 2006[1934]); A Gerschenkron, Economic Backwardness in Historical Perspective (Harvard UP 1962).

${ }^{17}$ W Bagehot, Lombard Street: A Description of the Money Market (Seven Treasures Publications 2009[1873]); J Rochet and J Tirole, 'Interbank Lending and Systemic Risk' (1996) 28 J Money, Credit, and Banking 733.
} 
creditors of banks - against individual or systemic insolvency and loss of savings deposited to a particular bank, has been discussed in the literature. This reflects the incentives of depositors to 'punish' banks if they happen to engage in riskier practices. ${ }^{18}$ Millions of depositors and creditors might find themselves stuck in a collective action problem, which may reduce the incentives for them to effectively monitor banks.

Additionally, besides depositor monitoring, market discipline ${ }^{19}$ is a more thorough monitoring mechanism. First of all, it depends on the investors' (i.e. depositor and/or creditors) ability to identify whether the bank is safe or not; and second, their reaction to the fundamentals of the bank being safe. If they are able to do so, then they can influence its behaviour. ${ }^{20}$ Suppose now that not all shareholders and depositors can have access to such information. Such access to information might not solve the asymmetric information problem due to potential moral hazard in reporting. ${ }^{21}$ Also, deposit insurance schemes could reduce the stakes in the effective monitoring of at least those depositors as shareholders and other creditors might have other channels to do so. ${ }^{22}$ Even in the case of the non-existence of moral hazard in information disclosure, the technicality and complexity of the contemporary banking and financial sectors restrict the level of expertise of consumers in these products and services.

The lack of effective monitoring through market mechanisms (and even regulation) might amplify the inherent risks in banking, as the spell and magnitude of financial cycles are longer and larger than in the past. ${ }^{23}$ Since the 1970 s, as Borio demonstrates, financial cycles are lasting longer than business cycles, and their magnitudes have increased since then. The effect of a downturn in the financial cycle is comparably larger than in the business cycle. We may argue that this new phenomenon might be caused by several factors. First, financial cycles have become more credit-driven as credit ${ }^{24}$ has become the lifeblood of any economy in the modern world. Second, corporate governance and arguably perverse incentives within each organisation have led to mismanagement and underestimation of risks due to pay schemes, proprietary trading, and bias toward riskier activities as bankers perform in an environment that prioritises risk-taking and lax stances on lending standards to boost income and profit. ${ }^{25}$

Increasing competition in the banking sector is known to motivate actors in the sector to engage in riskier activities. Foreign entry and capital account liberalisation in the past decades

\footnotetext{
${ }^{18}$ See M S M Peria and S L Schmukler, 'Do Depositors Punish for Bad Behavior? Market Discipline, Deposit Insurance, and Banking Crises' (2001) 56 The Journal of Finance 1029.

${ }^{19}$ Following A Crockett, 'Market Discipline and Financial Stability' (2002) 26 J Banking and Finance 977-987, market discipline is defined as "[t]o denote internal and external governance mechanisms in a free-market economy in the absence of direct government intervention" (ibid, 978). These governance mechanisms may include depositors and shareholders monitoring the bank, and banks monitoring each other through the interbank money market as they can have information about the others' leverage levels and liquidity requirements.

${ }^{20}$ M J Flannery, 'Market Discipline in Bank Supervision' in A N Berger, P Molyneux, and J O S Wilson (eds), The Oxford Handbook of Banking (Oxford UP 2010) 377.

${ }^{21}$ E Nier and U Baumann, 'Market Discipline, Disclosure and Moral Hazard in Banking' (2006) 15 J Financial Intermediation 332 .

${ }^{22}$ Lack of effective monitoring by depositors might emerge due to technicality in the banking and finance sectors, untimely reporting or even in cases of timely reporting access to that information might be limited, opaqueness of assets and liabilities of banks among other potential reasons, see M J Flannery, S H Kwan, and M Nimalendran, 'Market Evidence on the Opaqueness of Banking Firms' Assets' (2004) 71 J Financial Economics 419; M J Flannery, S H Kwan, and M Nimalendran, 'The 2007-2009 Financial Crisis and Bank Opaquenes' (2013) 22 J Financial Intermediation 55.

${ }^{23}$ C Borio, 'The Financial Cycle and Macroeconomics: What Have We Learnt?' (2014) 45 J Banking and Finance 182.

${ }^{24}$ Ò Jordà, M Schularick, and A Taylor, 'When Credit Bites Back' (2013) 45 J Money, Credit, and Banking 3.

${ }^{25}$ C A Hill and R W Painter, Better Bankers, Better Banks: Promoting Good Business through Contractual Commitment (The University of Chicago Press 2015).
} 
are known to produce implications for local competition ${ }^{26}$ as the former could reduce profits and thereby force the sector as a whole to find niches in the market which might sometimes be riskier activities that may offer higher returns in the short term even if they might have negative consequences in the longer term. Finally, the financial sector (and banking sector) is prone to euphoria and irrational optimism. ${ }^{27}$ The sector might take on illusions during 'good' times when asset prices and income is rising. Recently, Shiller pointed out that the irrationality behind these illusions resulted in the one of the worst financial and banking debacles since the Great Depression in the 1930s. ${ }^{28}$ In short, the shifts in the structure leading to rising competition in the sector will undoubtedly resonate at the individual level to search for niche areas in the market. This may in return breed a riskier attitude for an individual banker through, for instance, the existence of bonus schemes which rely on performance. ${ }^{29}$ Consequently, we can expect that the shifts in the structure can 'capture' the bankers so that the individual may ignore his or her identity within the wider society by only being motivated by performance indicators and the individual benefits those indicators bring about.

\section{(b) Regulators, Regulatory Capture, Public Interest}

Regulation plays an existential role in the supply and maintenance of public goods. The challenge arises precisely when one needs to make a distinction between a regulation that is in the interest of the society, or is benefitting a concentrated, easily mobilised, and selfinterested segment of the society. Defining and coding a given regulation being introduced in the name of maximisation of social welfare or for the private interests of a limited number of stakeholders is a rather difficult task. It is difficult because in order to code any regulation that is not serving the needs of a limited number of stakeholders but that is aimed to increase social welfare, we need at least three prerequisites for a clear codification after we are sure about what kind of regulation we are aiming to discuss. ${ }^{30}$ First, we have to define what is the first-best policy given no constraints could impede its implementation. Second, because we are generally in a second-best or even third-best world, we have to identify the preferences and interests of regulators. Third, the preferences and interests of the regulated industry should also be identified. Finally, the following step is to compare the policy, its content, and its implementation with the first-best policy based on regulators' preferences and those of the regulated industry. However, because such practice is out of the scope of this article, we can work through a simple dichotomy between public interest and regulatory capture. ${ }^{31}$

\footnotetext{
${ }^{26}$ S Claessens, A Demirgüç-Kunt, and H Huizinga, 'How Does Foreign Entry Affect the Domestic Banking Market?' (2001) 25 J Banking and Finance 891; R Sengupta, 'Foreign Entry and Bank Competition' (2007) 84 J Financial Economics 502; S Claessens and N van Horen, 'Foreign Banks: Trends and Impact' (2014) 46 J Money, Credit, and Banking 295.

${ }^{27}$ See the classical argument in C P Kindleberger, Manias, Panics, Crashes: A History of Financial Crises (Basic Books 1978).

${ }^{28}$ R J Shiller, Irrational Exuberance ( $3^{\text {rd }}$ edn, Princeton UP 2015).

${ }^{29} \mathrm{C}$ E Bannier, E Feess, and N Packham, 'Competition, Bonuses, and Risk-taking in the Banking Industry' (2013) 17 Review of Finance 653; H Hakenes and I Schnabel, 'Bank Bonuses and Bailouts' (2014) 46 J Money, Credit, and Banking 259; X Freixas, L Laeven, and J Peydrò, Systemic Risk, Crises, and Macroprudential Regulation (The MIT Press 2015).

${ }^{30}$ Mitnick argues that there are four types of regulations: a) benefits are concentrated while costs are diffused; $b$ ) both benefits and costs are concentrated; c) benefits are diffused but costs are concentrated; d) both benefits and costs are diffused, B M Mitnick, The Political Economy of Regulation: Creating, Designing, and Removing Regulatory Forms (Columbia UP 1980) 86-87. Consequently, we should have a clear understanding of what kind of regulation we are analysing as the literature on political economy of regulation can sometimes be ambiguous about the nature of the regulation the analysis is discussing.

${ }^{31}$ Besides public interest and capture theories, strands in the literature focusing on ideas and institutional strands can also give us extended channels of interpretation, $\mathrm{R}$ Baldwin, $\mathrm{M}$ Cave, and $\mathrm{M}$ Lodge, Understanding Regulation: Theory, Strategy, and Practice ( $2^{\text {nd }}$ edn, Oxford UP) Ch 4. Also, Levine and Forrence argue that capture and public interest approaches could be synthesised as the regulator might be a Burkean regulator whose
} 
Public interest à la Pigou holds the core assumption that regulation is conceived and designed to maximise social welfare. ${ }^{32}$ Therefore, it is implemented in the name of serving the good of the whole society. Regulators are expected to operate according to apolitical, objective policy targets that would not ceteris paribus benefit a small concentrated group vis-à-vis the society at large. ${ }^{33}$ What is problematic with the public interest approach is that it is very difficult to find a consensus on how to define and code a regulation which aims to maximise social welfare. Agents and principals might have their own conceptualisations of what public interest means. Also, finding the real origins of the public interest strand of political economy of regulation literature is very difficult, ${ }^{34}$ and is more positioned in the social welfare maximisation discourse. ${ }^{35}$ Consequently, researchers and even policymakers may find it challenging to work with the public interest approach particularly if they are looking for empirical evidence rather than building somewhat abstract theories or concepts. ${ }^{36}$

As opposed to public interest, the economic theory of regulation posits a more positivist approach to the political economy of regulation than a normative approach used by public interest. Carpenter and Moss define regulatory capture as "the result or process by which regulation, in law or application, is consistently or repeatedly directed away from the public interest and toward the interests of the regulated industry, by the intent and action of the industry itself." $" 37$ The theory assumes that actors attribute a relatively higher value to their own private interests. Buchanan and Tullock argue that even though individuals may have paradoxical motivations of self-interest and other-regarding interests in the political process, they are mostly conceived to be utility-maximisers in the market. ${ }^{38}$ In line with the public choice literature, the theory conceives public officials (here read as regulators) as utilitymaximising individuals operating in a (competitive) market. This core assumption claims that the political process of regulation motivates regulators to concentrate more on their private interests vis-à-vis focusing on social welfare because they can extract individual 'rents' for their own benefit.

The capture approach had been and is still being influenced by the relative ease of mobilisation, free-riding, utility-maximisation, and rent-seeking activities, and the dichotomy between private interests and other-regarding interests. Stigler claims that the regulated and

operations might be limited by the structure even if the agent or the agency would have public interest orientation, M E Levine and J L Forrence, 'Regulatory Capture, Public Interest, and the Public Agenda: Toward a Synthesis' (1990) 6 J Law, Economics and Organization 167.

${ }_{32}$ A C Pigou, The Economics of Welfare (Macmillan 1952[1920]).

${ }^{33}$ Strict regulations cause under-regulation which would in return provide incentives for the regulated industry to avert or create loopholes in the regulatory regime. Finding an optimal level of regulation even in the name of public interest and welfare is a challenging task for regulators, see C R Sunstein, 'Paradoxes of the Regulatory State' (1990) 57 The University of Chicago Law Review 407.

${ }^{34}$ M Hantke-Domas, 'The Public Interest Theory of Regulation: Non-Existence or Misinterpretation?' (2003) 15 European Journal of Law and Economics 1243.

${ }^{35}$ See P L Joskow and R G Noll, 'Regulation in Theory and Practice: An Overview' in G Fromm (ed) Studies in Public Regulation (The MIT Press 1981) 1.

${ }^{36}$ It is argued that capture may not be the rule as public interest could also be observed in practice. The author tries to extend the boundaries between the dichotomy of capture versus public interest. See S P Croley, Regulation and Public Interests: The Possibility of Good Regulatory Government (Princeton UP 2008); S P Croley, 'Beyond Capture: Towards a New Theory of Regulation' in D Levi-Faur (ed), Handbook on the Politics of Regulation (Edward Elgar 2011) 50.

${ }^{37}$ D P Carpenter and D A Moss, 'Introduction' in D P Carpenter and D A Moss (eds), Preventing Regulatory Capture: Special Interest Influence and How to Limit It (Cambridge UP 2014) 1, 13.

${ }^{38}$ J M Buchanan and G Tullock, The Calculus of Consent: Logical Foundation of Constitutional Democracy (University of Michigan Press 1965[1962]). 
the regulators may share common interests in lax stance of regulators; meaning that being captured by the regulated industry might be in their interest as well due to the possibility of individual gains. ${ }^{39}$ Peltzman extended Stigler's study by adding transfer of wealth from one segment of the society to the other. ${ }^{40}$ This is achieved through regulations. Small and concentrated groups have an advantage to easily convene and lobby regulators ${ }^{41}$ in comparison to, for instance, financial consumers or taxpayers in general in the area of banking regulation. Becker also argues that costs related to information gathering, and therefore mobilisation, are lower for concentrated and small groups. ${ }^{42}$ These underlying conditions increase the likelihood of regulatory capture. Regulators can prioritise their private gains due to the so-called revolving door incentives provided by the regulated sector. ${ }^{43}$ Laffont and Tirole argue that interest groups can utilise bribing, personal relationships, and indirect transfer to influence regulators. ${ }^{44}$

In the area of financial and banking regulation, regulators' role is to make sure that regulation and supervision are robust to make the system resilient particularly to unanticipated shocks. Regulators can be poised to the "host team bias", 45 the regulators are working with the banking sector closely. This close interaction may depend on asymmetric information the bankers can make a profit of by concealing essential data and information from the regulators. When the regulators do not have the capacity to access data, bankers can build leverage on asymmetric information. Or if they consider the importance of presenting themselves as capable agents, they can make regulations for their own benefit, but regulations will very likely be informed by demands of the sector. ${ }^{46}$ Also, lobbying is a well-known phenomenon to receive favourable treatment or influence regulators to have a softer stance on the regulatory framework. Consequently, regulatory capture may occur due mostly to asymmetric information, revolving door-types of arrangements between the sector and the regulators, and lobbying. 47

In summary, with respect to the interest of this article, if public interest prevails as the core motivation among regulators when formulating and implementing regulations, there would not be any conflict between their regulator and taxpayer identity since their regulator identity per se is attached to welfare of the society (i.e. taxpayers in general). However, since regulators can often neglect their taxpayer identity or be 'captured' by the regulated entities, it is necessary to focus on the implications of regulatory capture using a multiple identity approach.

\section{MULTIPLE IDENTITIES AND THEIR IMPLICATIONS FOR INCENTIVES}

Before the article discusses the application of a multiple identity approach on banking regulation, it first briefly focuses on the identity theory to provide a solid background for the

\footnotetext{
${ }^{39}$ G J Stigler, 'The Theory of Economic Regulation' (1971) 2 Bell Journal of Economics and Management Science 3.

${ }^{40}$ S Peltzman, 'Toward a More General Theory of Regulation' (1976) 19 J Law and Economics 211-240; S Peltzman, 'The Economic Theory of Regulation after a Decade of Deregulation' Brookings Articles on Economics Activity 1.

${ }^{41}$ See Olson's seminal work on free-riding and mobilization; M Olson, The Logic of Collective Action: Public Goods and the Theory of Groups (Harvard UP 1965).

${ }^{42}$ G S Becker, 'A Theory of Competition among Pressure Groups for Political Influence' (1983) 98371.

${ }^{43}$ J R Barth and R Levine, Rethinking Bank Regulation: Till Angels Govern (Cambridge UP 2006); J R Barth and R Levine, Guardians of Finance: Making Regulators Work for Us (The MIT Press 2012).

${ }^{44} \mathrm{~J}$ Laffont and J Tirole, 'The Politics of Government Decision-Making: A Theory of Regulatory Capture' (1991) 106 The Quarterly Journal of Economics 1089.

${ }^{45}$ J R Barth and R Levine, Guardians of Finance: Making Regulators Work for Us (The MIT Press 2012).

${ }^{46}$ A W A Boot and A V Thakor, 'Self-Interested Regulation' (1993) 83 The American Economic Review 206.

${ }^{47}$ E D Bó, 'Regulatory Capture: A Review’ (2006) 22 Oxford Review of Economic Policy 203.
} 
main thesis of this article. Identity is "the set of meanings that define who one is when one is an occupant of a particular role in society, a member of a particular group, or claims particular characteristics that identify him or her as a unique person". "I8 Identity stems from identification of the reflexive self to establish links between self and the group (Stets and Burke 2000). Individuals can form groups by either being physically together or through cognitive processes as in the form of the so-called "imagined communities". ${ }^{49}$ Examples of this are taxpayers who may never have the opportunity to meet but form this group to maintain a public good, namely the public budget; or financiers forming a professional group to produce financial and banking services. As individuals feel they are part of a particular group, they produce a group of "like-minded" individuals who share certain norms and principles which play a crucial role in the survival of the group. Those norms and principles are very likely to produce a shared ground for members as they are institutionalised and uniformity is built around perceptions and actions. ${ }^{50}$ The shared ground becomes the template according to which the individual may adjust her actions to seek congruence to the shared practice in the environment. ${ }^{51}$

An identity attached to a group also comes along with roles played in this group. And those (social) roles are "expectations attached to positions occupied in networks of relationships; [and] identities are internalised role expectations". ${ }^{52}$ The individual starts acting in accordance with the expectations of the role in line with self-meanings and the aim of receiving (positive) feedback from group members, and thus in time and through internalisation, the individual (and the group itself) perceive things through a common lens. ${ }^{53}$

As the identity theorists recognise, individuals are a member of various groups. ${ }^{54}$ All these groups assign particular roles to the individual. Those roles might operate in harmony, however, they can also contradict each other. The latter is a more interesting case because we then have to understand how the individual could balance conflicting identities (i.e. social roles in each group) and the balancing process. Due to our membership in many groups, or roles, individuals have to grapple with salience hierarchy. ${ }^{55}$ Salience hierarchy simply tries to understand the likelihood of activation of an identity in a given context. Our preferences are attached to our roles, and the process of defining the hierarchy according to the salience of an identity determines our behaviour. This process comes along with competition between identities they sometimes clash. ${ }^{56}$ As a result, how we define the hierarchy between our identities according to salience in a given context appears to be important to understand our behaviour, but the process is not so simple as we have to sail through conflicting identities and roles attached to each of them. ${ }^{57}$

\footnotetext{
${ }^{48} \mathrm{P} \mathrm{J}$ Burke and J E Stets, 'Agency and Social Structure' in P J Burke and J E Stets (eds), Identity Theory (Oxford UP 2009) 3, 3.

${ }^{49}$ B Anderson, Imagined Communities: Reflections on the Origin and Spread of Nationalism (Verso 2006[1983]).

${ }^{50}$ J E Stets and P J Burke, 'Identity Theory and Social Identity Theory' (2000) 63 Social Psychology Quarterly 224.

${ }^{51}$ P J Burke, 'Identity Process and Social Stress' (1991) 56 American Sociological Review 836.

${ }^{52}$ S Stryker and P J Burke, 'The Past, Present, and Future of an Identity Theory' (2000) 63 Social Psychology Quarterly 284, 286.

${ }^{53}$ Stets and Burke (n50).

${ }^{54}$ P J Burke and J E Stets (eds), Identity Theory (Oxford UP 2009).

${ }^{55}$ S Stryker, Symbolic Interactionism: A Social Structural Version (Blackburn Press 2002[1980]).

${ }^{56} \mathrm{P}$ A Thoits, 'Multiple Identities and Psychological Well-Being: A Reformulation and Test of the Social Isolation Hypotheses' (1983) 48 American Sociological Review 174.

${ }^{57}$ D Kelsey, 'Utility and the Individual: An Analysis of Internal Conflicts' (1986) 3 Social Choice and Welfare 77; C Binder, 'Plural Identities and Preference Formation' (2014) 42 Social Choice and Welfare 959.
} 
Motivated by the brief discussion about the process of determination of the hierarchy among identities, this article recognises the need to apply to identity theory on the political economy of banking regulation. Besides the identity theory itself, the multiple identity approach in this article is inspired by the economic theory of identity. ${ }^{58}$ Akerlof and Kranton brought the identity issue to the attention of economics by arguing that the rationality assumption depends upon our implicit assumption of the single identity approach. ${ }^{59}$ They underlined the importance of individuals deriving and maximising utility ${ }^{60}$ through their identification with other individuals and/or groups. Sen focuses on the relationship between identity and violence. ${ }^{61}$ Sen reflects on the possibility of the various identities we have, and how individuals may act according to the dictates of these identities. ${ }^{62}$ Finally, Davis argues that individuals have to cope with a 'multiple-selves' problem. ${ }^{63} \mathrm{~A}$ rational decision in one context and at a given certain period of time may not be rational as the individual may no longer conceive this decision as rational and change his or her position accordingly.

Multiple identity approach can motivate us to search for additional ways to conceptualise regulation of the banking sector at the agency level. Sen argues that "belonging to each one of the membership groups can be quite important, depending on the particular context. When they compete for attention and priority over each other... the person has to decide on the relative importance to attach to the respective identities, which will, again, depend on the exact context." "He challenges our conception of what he calls the "singular affiliation" assumption. ${ }^{65}$ For him the context is so vital that the individual will have to be first cognisant of her identities, and then balance these identities before opting for an 'optimal' behaviour, which is also in line with the identity verification process and salience hierarchy the identity theorists discuss. ${ }^{66}$

In the area of banking regulation, we can conceptualise incentives for a banker and a regulator according to two institutional settings, namely their taxpayer identity, and their banker or regulator identity. The taxpayer identity is a common social identity that bankers and regulators share with others in the same jurisdiction they are living in. Besides the shared taxpayer identity, they also possess banker or regulator identities. What is related to the taxpayer, and banker or regulator identity is that when an individual or a systemic bank failure occurs, taxpayers' money is generally utilised to save the banking and financial sector. Because all taxpayers pay their own share, bankers and regulators cannot avoid contributing to the common property the whole society owns. Motivated by such reasoning, this section will show why multiple identities work according to different incentive mechanisms, and why they are important in regulation of the banking sector.

\footnotetext{
${ }^{58}$ Akerlof and Kranton; Sen; Davis (n8).

${ }^{59}$ G A Akerlof and R E Kranton, 'Economics and Identity' (2000) 115 The Quarterly Journal of Economics 715; G A Akerlof and R E Kranton, Identity Economics: How Our Identities Shape Our Work, Wages, and Well-being (Princeton UP 2010).

${ }^{60}$ The authors introduce the concept of identity utility. It means that individual derive utility not just because of the rationality of their choices, and therefore serving the good of the individual, they can also derive and maximize utility according to their identities.

${ }^{61}$ A Sen, Identity and Violence: The Illusion of Destiny (W.W. Norton\& Co 2006).

62 ibid, 19-21.

${ }^{63} \mathrm{~J}$ B Davis, Individuals and Identity in Economics (Cambridge UP 2011).

${ }^{64}$ A Sen, Identity and Violence: The Illusion of Destiny (W.W. Norton\& Co 2006), 19.

65 ibid, 23-28.

${ }^{66}$ Stryker (n55).
} 
The institutional setting the banker faces is based on profit maximisation and maximisation of efficiency in terms of lower operation costs, higher margins, and higher returns on assets and equity, according to Minsky. ${ }^{67}$ Their profit orientation motivates them to take excessive risks. While their banker identity dictates excessive risk-taking, their taxpayer identity would request a contradictory behaviour, which is to be much more prudent than what the banker identity would ask from the individual. Although we may assume that a typical Downsian taxpayer may not have well-established preferences on the (fiscal) costs of banking crises, a banker might be assumed to have an understanding of potential results of excessive risktaking even if this might rely on imperfect knowledge. As a result, we can claim that they might be cognisant of negative externalities of failures, however, balancing the banker and the taxpayer identity is challenging.

Therefore, we have to explain why bankers may not be able to balance the contradictory incentives they are facing at the same time. Because bankers have to balance their preferences formed by two respective identities, the underlying cause of the imbalance and more value attributed to the banker identity in excessive risk-taking by neglecting a larger role shared by the public, might be what George mentions as the prevalence of the first-order preferences against those of the second-order. ${ }^{68}$ For George individuals are driven by preferences produced by market forces. ${ }^{69}$ As markets produce both good and bad preferences, individuals may end up choosing the bad preference due to the divergence between revealed and desired preferences. A banker, for instance, might consider risk-taking activities as the first-order preference, and a prudent behaviour as the second-order preference, since the structure and the market dictates a certain motivational framework. The result of the process of balancing these two preferences is assumed to be mostly dominated by the first-order preference because the market structure forces individuals to that end. George's conceptual framework sounds as if a clash between the agent and the structure where the structure determines the outcome. ${ }^{70}$ The framework does not allow for a dual relationship between the agent and the structure. ${ }^{71}$ However, it is nonetheless useful for us to have an idea of why bankers may not be able to balance their private gains as a banker against their common identity as a taxpayer, especially if bankers are motivated by material benefits. ${ }^{72}$

If bankers are more motivated by material rewards that are produced by market forces, how can we explain the dominance of market forces on bankers' behaviour, which in return leads to their negligence of taxpayer identity? One could be the level of competition in the market particularly with the entry of foreign banks or local banks. A more competitive market structure is known to be more prone to instability ${ }^{73}$ which might be driven by higher risk appetite in its search for niche areas with higher margins. Second, payment and bonus schemes in the banking sector have been discussed particularly after the recent global

\footnotetext{
${ }^{67}$ H P Minsky, Stabilizing an Unstable Economy (Foreword with Henry Kaufman, McGraw Hill 2008[1986]), 256.

${ }^{68}$ D George, Preference Pollution: How Markets Create Desires We Dislike (University of Michigan Press 2001). 
financial crisis. ${ }^{74}$ Third could be deregulation in the banking sector. Deregulation in terms of entry might result in a more competitive market structure which may allow allocation of as much credit as the sector can allow, even if the sector or the economy could face stability concerns later on. ${ }^{75}$ The fourth reason could be long-run lower interest rates that motivate bankers to lend more, and borrowers to borrow more. Fifth, particularly in developing countries, capital inflows are likely to result in a boom in credit allocation. ${ }^{76}$ Finally, corporate governance measures in a given entity may not be conducive enough to find a sustainable and robust equilibrium point that could balance the tendency toward excessive risk-taking and a more prudent stance on risk-taking.

From the regulators' approach, their mandates prioritise public interest and social welfaremaximisation. The challenge for them to balance their taxpayer identity with their regulator identity may seem less of a concern in comparison to a banker whose first-order preference is to maximise profit. However, this does not mean that regulators might find the balance between the first-order and second-order preferences. This is because the first-order preference of regulators may change from the lens we are analysing the balance between the two identities they have. If we are analysing with a regulatory capture lens as assuming that the second-order is to maximise social welfare, the first-order preference is to maximise private gains for instance through the revolving door mechanisms. ${ }^{77}$ Here, it is worth noting that the revolving door argument posits that regulators are offered tangible benefits for regulatory forbearance or lax stances such as in the form of career in the regulated industry. The regulatory agencies may also staff the agency with former bankers. In this case, a relic identity ${ }^{78}$ would expect that the regulator whose dominant role requires the regulator to focus only on the official mandate of the agency might be under pressure from the former banker role which may lead unnecessary sympathy with the sector resulting to regulatory forbearance. However, if we consider the possibility of public interest orientation against a case of regulatory capture, the first- and second-order preferences overlap. Thus, we should not observe any contradiction between the taxpayer identity and regulator identity.

Although we can consider the possibility of public interest orientation among regulators at least in theory, since the recent global crisis, it has been thoroughly discussed that the regulators had a lax stance on regulating the banking sector. As this seems to be the conclusion so far, we have to understand what factors might overshadow the public interest orientation among regulators. First of all, a public interest approach implicitly assumes that regulators may be better informed than the market actors. However, when we relax this assumption under conditions of imperfect knowledge and information, ${ }^{79}$ bounded rationality ${ }^{80}$ might prevail besides other cognitive limitations such as confirmation bias, heuristics, myopia among others that cause such limitations. ${ }^{81}$ In this case, the level of knowledge regulators

\footnotetext{
${ }^{74}$ Bannier, Feess, and Packham; Hakenes and Schnabel; Freixas, Laeven, and Peydrò (n29).

${ }^{75}$ Ò Jordà, M Schularick, and A Taylor, 'When Credit Bites Back' (2013) 45 J Money, Credit, and Banking 3; Ò Jordà, M Schularick, and A Taylor, 'Sovereigns Versus Banks: Credit, Crises, and Consequences' (2015) 14 J European Economic Association 45.

${ }^{76}$ D Igan and Z Tan, 'Capital Inflows, Credit Growth, and Financial Systems' International Monetary Fund Working Paper 15/193, 19 August 2015.

${ }^{77}$ J R Barth and R Levine, Guardians of Finance: Making Regulators Work for Us (The MIT Press 2012).

${ }^{78}$ E Gross and G P Stone, 'Embarassment and the Analyss of Role Requirements' (1964) 71 American Journal of Sociology 1.

${ }^{79}$ F A Hayek, 'The Use of Information in Society' (1945) 35 The American Economic Review 519.

${ }^{80}$ H A Simon, ‘A Behavioral Model of Rational Choice' (1955) 69 The Quarterly Journal of Economics 99.

${ }^{81}$ D Kahneman and A Tversky, 'Prospect Theory: An Analysis of Decision under Risk' (1979) 47 Econometrica 263; D Kahneman, Thinking, Fast and Slow (Farrar, Straus and Giroux 2011); S Tasic, 'Are Regulators
} 
have might be decisive during the policy design stage if the regulatory framework in a way cannot fully address the requirements of the market while providing leeway for the market actors to play their tacit/informal knowledge about the system against the regulatory framework. Imperfect knowledge and cognitive limitations are important especially when regulators have to cooperate with the banking sector. ${ }^{82}$ During their interaction with the banking sector, the sector may aim to use its leverage stemming from its advantage of higher level of information and knowledge against the regulators to manipulate the policy design process.

Second, as discussed previously, when regulators' self-interest in terms of individual gains and the attempts by the regulated industry, and/or preferences of the political authority converge, it is very likely that capture occurs. Convergence of preferences might be the result of the market structure where a concentrated banking sector finds it easier to influence regulators. ${ }^{83}$ Or 'political capture ${ }^{84}$ may occur due to the subordinate position of the (independent) regulatory agency vis-à-vis the political principal.

Third, with the diffusion of the so-called 'regulatory state,' the independence of regulatory agencies might be assumed to have enabled regulators to operate according to public interest due to isolation from the daily political concerns, and pressure from politicians. ${ }^{85}$ On the other hand, we might also observe that they are isolated from the accountability to the public, while they might be less shielded against the influence of the regulated industry. Independence and its implications for accountability of the agency have other essential aspects. The lack of feedback mechanisms that might be utilised by the public to inform regulators about the effectiveness of regulations may not work as imagined, particularly when the sector aims to shield the agency from other stakeholders. As a result, the 'home team bias ${ }^{96}$ may leave the regulators in the hands of bankers as 'cultural capture' in terms of accommodative regulatory practices could be the result of interactions between the regulators and bankers. ${ }^{87}$

Both bankers and regulators can avoid "role conflict". ${ }^{88}$ Goffman identifies two strategies individuals use to avoid role conflict. ${ }^{89}$ The first is role segregation. Individuals assume only one role at a given time, and they can easily change from one role to another. The second is audience segregation. While playing dissimilar roles in different environments, we also try to

Rational?' (2011) 17 Journal des Economistes et des Etudes Humaines 1; J C Cooper and W E Kovacic, 'Behavioral Economics : Implications for Regulatory Behavior' (2012) 41 J Regulatory Economics 41.

${ }^{82}$ Barth and Caprio (n77).

${ }^{83}$ K Young and S Pagliari, 'Capital United? Business Unity in Regulatory Politics and the Special Place of Finance' (2015) Regulation \& Governance (forthcoming).

${ }^{84}$ Schnellenbach and Schubert highlight that regulators may find easier to address salient issues that could be more easily targeted. We can also add the politically salient and more easily targeted parts of the regulatory framework that might be addressed due to the preferences of the political authority; see J Schnellenbach and C Schubert, 'Behavioral Political Economy: A Survey' (2015) 40 European Journal of Political Economy 395.

${ }^{85}$ M Moran, 'Review Article: Understanding the Regulatory State' (2002) 32 British Journal of Political Science 391; D Levi-Faur, 'The Global Diffusion of Regulatory Capitalism' (2005) 598 Annals of the American Academy of Political and Social Science 12; J Jordana, D Levi-Faur, and X F I Marin, 'The Global Diffusion of Regulatory Agencies: Channels of Transfer and Stages of Diffusion' (2011) 20 Comparative Political Studies 1; J Jordana, 'The Institutional Challenges on the Regulatory State in the Developing World' in N K Dubash and B Morgan (eds), The Rise of the Regulatory State of the South: Infrastructure and Development in Emerging Economies (Oxford UP 2013) 198.

${ }^{86}$ Barth and Caprio (n77).

${ }^{87}$ J Kwak, 'Cultural Capture and the Financial Crisis' in D Carpenter and D A Mos (eds), Preventing Regulatory Capture: Special Interest Influence and How to Limit It (Cambridge UP 2014) 71.

${ }^{88}$ S Scott, Negotiating Identity: Symbolic Interactionist Approaches to Social Identity (Polity 2015) 104-105.

${ }^{89}$ E Goffmann, Encounters: Two Studies in the Sociology of Interaction (Bobbs-Merrill 1961). 
avoid performing to the same audience. The latter also gives us the advantage to benefit from asymmetric information vis-à-vis the outside audience. This is relevant in our analysis here in a way that both bankers and regulators can disguise information from the whole society on whose shoulder they transfer the burden of bank failures and financial instability. By playing different roles and segregating audiences, they benefit from asymmetric information until the emergence of rare focusing events enabling others to beware of deficiencies in the system.

Finally, the structural forces that are leading to the negligence of the second social identity that connects the individual to the society is what we claim leads to preference pollution. ${ }^{90}$ Bankers and regulators might be engulfed in particular narrow social roles and lose sight of a comprehensive understanding of potential risks they are transferring on the rest of the society while they also have to pay their share in terms of tax after the intervention of the public sector to rescue the system. Engulfment is the result of a very high level of internalisation of social norms and standards of narrow roles, and both may lose the capacity to distance themselves from their respective narrow roles. ${ }^{91}$

\section{MULTIPLE IDENTITIES AND POLITICAL ECONOMY OF BANKING REGULATION}

This article argues that bankers and regulators are sharing a common identity with the rest of the society, viz. taxpayer identity. Besides their respective and banker and regulator identities, bankers and regulators are also part of the society as contributors to a common property, namely the public budget, which is generally used to cover individual and/or systemic bank failures.

Figure 1: The Politico-Economic Structure

\footnotetext{
${ }^{90}$ George (n68).

${ }^{91}$ D A Snow and L Anderson, 'Identity Work among the Homeless: The Verbal Construction and Avowal of Personal Identities' (1987) 92 American Journal of Sociology 1336; S Scott, Negotiating Identity: Symbolic Interactionist Approaches to Social Identity (Polity 2015) 104-105.
} 


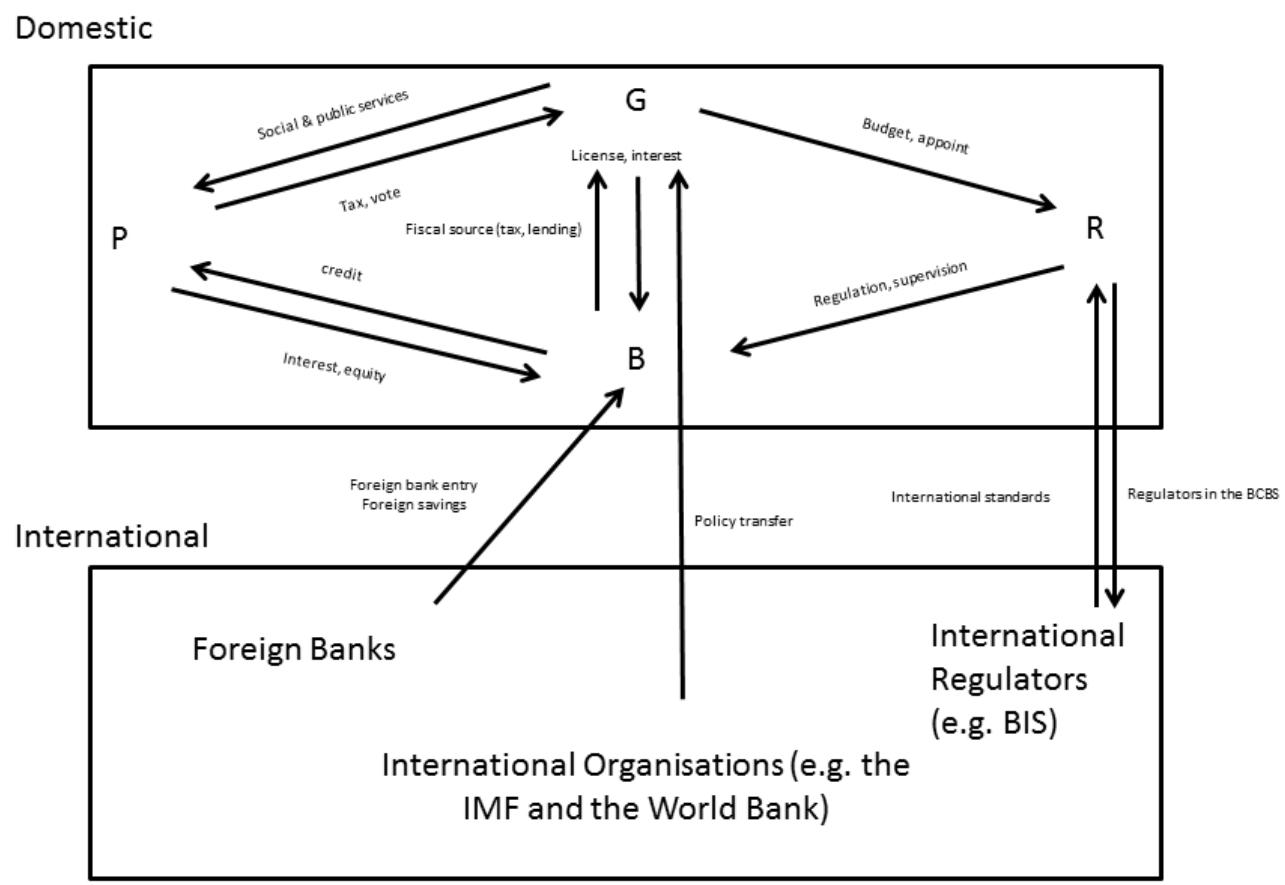

Figure 1 shows a simple illustration of a politico-economic structure in which the banking sector and regulators are operating. In the domestic arena, "P" involves households and firms. "G" is government. " $R$ " symbolises the regulators. Finally, " $B$ " is local banks. Figure 1 also incorporates interactions with the international arena because it would be naïve to assume a closed economy model in the contemporary world..$^{92}$

Before we discuss what Figure 1 tells us, let us first of all highlight a few assumptions behind the framework. First, since this article is more individual-oriented, it ignores firms as part of "P". Second, it assumes that there is a single and independent regulator overseeing the stability of the banking sector. Third, although it recognises the importance of interaction with international actors, it abstracts from the dynamics governing such interaction. ${ }^{93}$ Given these conditions, what Figure 1 tries to tell us is multi-faceted. First, it signifies that both bankers and regulators are part of "P." Being part of "P" constitutes the main argument in this article because it provides the rationale why this article introduced the taxpayer identity into the

\footnotetext{
${ }^{92}$ See D Drezner, All Politics is Global: Explaining International Regulatory Regimes (Princeton UP 2007). It is out of the scope of this paper to analyse the implications of interactions with the international actors for the local bankers and regulators to balance banker/regulator and taxpayer identities. However, this seems to be an important area for future research because as in the case of new membership of emerging market economies to Basel Committee on Banking Supervision (BCBS) in2009, we can expect that the transfer of international standards may change the nature of the interaction between the actors. Previously a frequent case of regulatory capture in these economies due to a somewhat symbiotic relationship between the actors could take a new nature as the regulators now need to comply with the BCBS requirements due to membership. If this channel is working as hypothesised, then we should observe easiness for regulators to identify themselves with the taxpayer identity with a more prudent approach although they may still be subjected to pressure from the sector.

${ }^{93}$ The discussion in this article could be applied to various contexts, however, since the politico-economic structures assumes that regulators are also part of the Basel Committee on Banking Supervision (BCBS), the dynamics of interaction with the BCBS might be different although Basel regulations are adopted in the IMFWorld Bank Financial Stability Assessment Programme (FSAP) since the launch of the Core Principles for Effective Banking Regulation by the BCBS in the early 2000s.
} 
political economy of banking regulation. This motivation relies upon the outcry among taxpayers, on the use of taxpayers' money to capitalise and rescue the financial and banking sectors after the global financial crisis. The pool of resources the regulators tapped into is a common property of the whole society similar to a lake where all fishermen are using the resource for their own benefit. The norms based on previous experiences require public intervention to maintain and/or re-establish stability in the system. This is possible with putting the burden on the fiscal sources of the public sector. And, this fiscal source is a pool where all taxpayers contribute to varying degrees based on income, volume and amount of transactions, and so forth. Since this pool is a common property, every citizen has a right and responsibility to contribute and oversee its good management. During crises, this pool is mobilised, and this causes socialisation of costs of failures particularly during financial crises.

As discussed earlier, when individuals or separate groups as bankers and regulators irresponsibly neglect the common property they are tapping, this common property could be used so much that severe consequences such as sovereign debt crises become much more likely as in the case of Greece and Ireland. ${ }^{94}$ As a result, the cost of regulatory forbearance or lax stance on regulation among regulators, and excessive risk-taking among bankers, is transferred to others' shoulders while they as taxpayers also have to share it with other taxpayers. From bankers' and regulators' point of view, this outcome could be preferred, especially when individual benefits might shadow socialised costs if all goes wrong and the system fails.

Second, aside from regulators' and bankers' role in maintenance of a common property, another challenge is that from a Downsian and Olsonian public choice perspective, ${ }^{95}$ other members of "P" (read this as the rest of the society) may not always be able to keep the regulatory agency and the banking sector accountable to itself due to the so-called 'irrational rationality'. ${ }^{96}$ This means they may not be willing to seek information and/or participate in the political process, because in the case of an individual or a systemic bank failure, the costs related to bail-outs are diffused among millions of taxpayers and voters. The diffused structure of costs and their compensation by the use of tax monies may not motivate a typical taxpayer to be worried about those costs. Additionally, in the era of the so-called 'regulatory state', accountability of (independent) regulatory agencies has become much more problematic for taxpayers ("P" in Figure 1)..$^{97}$

Also, (credible) deposit insurance schemes, difficulties related to market discipline mechanisms, and moral hazard in information disclosure make monitoring more demanding. ${ }^{98}$ As mentioned earlier, banks serve as monitoring agents on behalf of depositors (and creditors). ${ }^{99}$ This may cause a typical free-riding and collective action problem because the

\footnotetext{
${ }^{94}$ Jordà, M Schularick, and A Taylor, 'Sovereigns Versus Banks: Credit, Crises, and Consequences’ (2015) 14 J European Economic Association 45.

${ }^{95}$ A Downs, An Economic Theory of Democracy (Harper 1957); M Olson, The Logic of Collective Action: Public Goods and the Theory of Groups (Harvard UP 1965).

${ }^{96}$ B Caplan, The Myth of Rational Voter: Why Democracies Choose Bad Policies (Princeton UP 2007).

${ }^{97}$ C Scott, 'Accountability in the Regulatory State' (2000) 27 J Law and Society 38; J Black, 'Constructing and Contesting Legitimacy and Accountability in Polycentric Regulatory Regimes' (2008) 2 Regulation \& Governance 137; M Lodge and L Stirton, 'Accountability in the Regulatory State' in R Baldwin, M Cave, and M Lodge (eds), The Oxford Handbook of Regulation (Oxford UP 2010) 349.

${ }^{98}$ M S M Peria and S L Schmukler, 'Do Depositors Punish for Bad Behavior? Market Discipline, Deposit Insurance, and Banking Crises' (2001) 56 The Journal of Finance 1029; L Laeven, 'Corporate Governance: What's Special about Banks?' (2013) 5 Annual Review of Financial Economics 63; F Allen and others, 'Moral Hazard and Government Guarantees in the Banking Industry' (2015) 1 J Financial Regulation 30.

${ }^{99}$ Diamond (n15).
} 
number of depositors are so large that they cannot easily solve preference problems to reach a consensus, and therefore act together to make banks accountable for their (riskier) activities. When this is the case, "P" may find mechanisms to hold both regulators and bankers accountable due to restricted access and/or free-riding concerns.

Therefore, when these underlying conditions are taken into account, we can claim that the society can find itself in a sub-optimal area where implicit or explicit collusion among bankers and regulators can transfer a huge burden on their taxpayers' shoulders. Since there is generally a lack of credible channels for the society to keep two actors accountable to itself, the downside risks of not being able to find a balance between the banker/regulator and taxpayer identities are too high. Since both actors struggle very much to find the balance between the taxpayer identity they share with other members of the "P", or the banker or regulator identities they share with a limited number of members of " $B$ " and " $R$ ", adverse incentives in the market and lack of effective control and accountability mechanism emerge as the primary failing parts of the system to sustain financial stability.

\section{HOW TO ADDRESS THE MULTIPLE IDENTITY PROBLEM?}

The previous sections introduced the possibility of multiple identities with the aim of emphasising their potential role in rethinking banking regulation, because the main argument shows that thinking carefully about finding ways to align incentives of multiple identities might be much more important. In this regard, this section discusses two mechanisms as policy recommendations with the aim of improving accountability of bankers and regulators to public, and ownership in financial stability among bankers and regulators.

Figure 1 above presented a simple picture of the politico-economic structure surrounding the political economy of banking regulation. One of the assumptions behind it was the single and independent regulatory agency overseeing the stability of the sector. However, the reality can be more complicated because there might be multiple regulators. ${ }^{100}$ The above framework could be improved by introducing other public authorities in the political economy of banking regulation. Within this regulatory governance structure, suppose there is an independent banking regulator and a central bank as the monetary authority. The regulator is mandated to supervise and regulate, while the central bank manages liquidity, payment systems, and reserve system. The central bank could play a veto player ${ }^{101}$ role by either implementing contradictory policies and/or attempts to persuade the banking regulator through inter-agency communication channels to be more prudent if the regulator is captured and neglects its taxpayer identity (i.e. its public interest role). But, this assumes that the central bank is independent, ${ }^{102}$ have a better institutional standing vis-à-vis the regulator. Although both of the organisations might have independence from the political authority, a veto player which has a higher level of institutional capacity might be useful as a veto player against a potentially captured regulator.

\footnotetext{
${ }^{100}$ I wish to thank one of the anonymous referees pointing out the need to improve the framework by making more factors such as the existence of various public authorities that may have dissimilar preferences endogenous to the framework.

${ }^{101}$ G Tsebelis, Veto Players: How Political Institutions Work (Princeton UP 2002).

102 If the central bank is not independent, this mechanism is not preferred. Politics is always everywhere so both organisations could operate under political pressure. If the central bank has somewhat superior capabilities, but is not independent, the regulator will be a very subordinate actor in the policymaking process that it may not fulfil its mandate. As a result, those and similar concerns must be equally weighted before a regulatory structure is introduced.
} 
Therefore, if a given society lacks a credible and independent banking regulator, a multiple regulatory structure could be the second-best institutional arrangement provided the central bank is better endowed, but the regulator does not lack sufficient resources to regulate and supervise the sector. The downside of such an arrangement is that the regulatory governance structure must be so efficient and effective that a clash between organisations can leave the policymaking process in a stalemate, and this is not desired if one is concerned with financial stability and resiliency of the sector.

The second mechanism is related to bail-in and bail-out resolution mechanisms. Implicit and/or explicit government guarantees in the forms of deposit insurance ${ }^{103}$ and implicit or explicit bail-out guarantees ${ }^{104}$ are well-known to give rise to a tendency of (excessive) risktaking among bankers and forbearance among regulators as both actors know that the public sector may intervene in the system in case of a failure.

As stated earlier, Avgouleas and Goodhart have recently reviewed the advantages and disadvantages of bail-in and bail-out measures. ${ }^{105}$ Bail-out measures are costly for taxpayers, but they are relatively much more easily implemented so that a deeper crisis can be averted. While this appears as the main advantage, bankers might get induced to take more risks with the expectation of capitalisation during a financial downturn. On the other side, bail-in measures can boost ownership among bankers because they will know they will have to incur costs of a failure. However, bail-in is costly for banks, and the process might be halted due to liquidity concerns in the market and within the bank.

From a regulator's perspective, we may assume that in the case of bail-out and other explicit or implicit government guarantees, regulators are prudent to maximise social welfare without resorting to tax monies because they are aware of fiscal costs of bank failures. But, in the case of bail-in, they might be incentivised to have a lax stance on the regulatory framework because they can assume that banks and their creditors are expected to cover losses not taxpayers.

Given these scenarios, we may need to reconsider the advantages and disadvantages of bail-in and bail-out measures in the light of a multiple identities problem. Rather than feeling the pressure to choose between the two, it might be more reasonable to find a balance between these two approaches as a crisis resolution mechanism. This seems important because bail-in measures can boost ownership among bank creditors to monitor the system, and therefore bankers to have a higher stake and ownership in the stability of the system. Bail-out measures can motivate regulators to feel ownership and perhaps improve an accountability channel due to tapping public budget to rescue the system. Having both together at the same time in a policy toolkit, as proposed below, could address the multiple identity of two actors because choosing one motivates the other to shirk. If we for instance just rely on bail-in measures, the bankers can feel responsibility if the system fails. If bail-out measures are chosen, then the bankers can shirk, but now regulators might feel ownership. Consequently, having the two

\footnotetext{
${ }^{103}$ M S M Peria and S L Schmukler, 'Do Depositors Punish for Bad Behavior? Market Discipline, Deposit Insurance, and Banking Crises' (2001) 56 The Journal of Finance 1029; A Demirgüç-Kunt, and H Huizinga, 'Market Discipline and Deposit Insurance' (2004) 51 J Monetary Economics 375; F Allen and others, 'Moral Hazard and Government Guarantees in the Banking Industry' (2015) 1 J Financial Regulation 30.

${ }^{104}$ R Gropp, H Hakenes, and I Schnabel, 'Competition, Risk-shifting, and Public Bail out Policies' (2011) 24 The Review of Financial Studies 2084.

${ }^{105}$ E Avgouleas and C Goodhart, 'Critical Reflections on Bank Bail-ins' (2015) 1 J Financial Regulation 3.
} 
together can serve the needs of the society, although we cannot escape from the political economy dynamics that govern how the two mechanisms will be used.

The balance between two types of resolution mechanisms could be established in various ways. ${ }^{106}$ In case of a bank failure regardless of its size (e.g. individual or systemic), first of all banks could be forced to incur the costs of that failure although balance sheet exposures may not facilitate this process. However, the regulators may use asymmetric information about the timing of a potential intervention which could be until the system starts showing signs of a dramatic downturn. When this is the major concern, regulators can intervene to correct the failure, and to buffer other areas in the economy.

The aforementioned mechanism of bail-in could work through the interbank market. Banks lend and borrow from each other in the interbank market. Because they are aware of their peers' liquidity needs in the interbank market and interconnections in their balance sheets, they can monitor each other. The mechanism could work as not requesting a single entity to bail-in itself, but regulate in a way that banks can share the burden in the sector until regulators feel the market needs a third party's guidance in the market.

The third solution could as part of bail-in measures could be, "covenant banking" 107 which might be adopted as the primary business model that prioritises ownership in resiliency in and solvency of the banking sector. The authors argue that the change in business model from relationship banking to market-based banking's more competitive mode that is accompanied with limited liability for individual bankers has made the sector more prone to excessive risktaking and moral hazard kind of perils. ${ }^{108}$ The individual bankers should be made liable to whatever the cost is. Unless they are held liable and accountable and public implicit or explicit guarantees remain in place, it is very likely that they may not be forced to be accountable and feel ownership in stability of the system.

These mechanisms are supposedly considered to, first of all, give banks incentives to maintain higher capital adequacy levels and buffers. ${ }^{109}$ Second, depositors alongside creditors may feel they have a higher stake in the stability of the system as their own deposits might be transformed into equity shares in the bank whose market value might be so low that investing in that bank might not be a rational choice. Third, banks could become more prudent as they realise that it is in their interest to monitor each other even in a very competitive market because it is very likely that when at least one them fails, the whole sector might approach the brink of a systemic crisis. As a result of that, bankers could develop a higher level of ownership in the stability of the system by closely watching the health of the bank and the sector itself.

As for regulators, because of the unique feature of the 'regulatory state' and its independent regulatory agencies, they do not have direct mechanisms of accountability to the public. The creation of a direct channel might be desirable. This could be achieved with a legal process,

\footnotetext{
${ }^{106}$ These mechanisms do not necessarily help us avert political economy concerns when we are to implement them. The suggestions in this article have a ceteris paribus assumption when offering these possibilities. Further empirical and theoretical studies are needed to demonstrate their (un)feasibility.

${ }^{107}$ C A Hill and R W Painter, Better Bankers, Better Banks: Promoting Good Business through Contractual Commitment (The University of Chicago Press 2015).

${ }^{108}$ ibid, Ch 2.

${ }^{109}$ Financial Stability Board (FSB) drafted a consultation document on the so-called total loss absorption capacity of globally systemically important banks (G-SIBs). The measures include capital buffers in additional to Basel III regulations. The document is available at: http://www.financialstabilityboard.org/2014/11/adequacy-ofloss-absorbing-capacity-of-global-systemically-important-banks-in-resolution/, accessed on September 2, 2015.
} 
preferably the legislature opens up an inquiry process about regulators' ex ante stance within the legislature. This process could be the result of their ex ante and ex post stance on the regulatory framework. They might be questioned about their ex ante lax stance and/or policies implemented during and after a crisis. As of today, many independent regulatory agencies are not fully accountable about their policies due to the lack of such measures, which may in return reduce their incentives to feel more ownership in the stability of the system. Their mandate and/or their taxpayer and voter identity may not help for the public to solve conflicts of interest.

In brief, regulation of a system defines the boundaries of legitimate social behaviour in this system. The new wave of regulations addressing deficiencies that have become visible with the global crisis is an attempt to redefine such boundaries. Before the crisis, the banker identity allowed engagement in riskier activities, while regulators were somehow allowed to ignore missing and malfunctioning parts in the regulatory framework. After the global crisis, the boundaries of legitimate social behaviour have been subjected to negotiations and redefinition around the world. As we are redefining the boundaries of each identity individuals have, finding solutions to the multiple identity problems appears to be a crucial concern despite difficulties to find appropriate mechanisms to address such a complicated problem.

\section{CONCLUSION}

This article revisited the literature on the incentives of both bankers and regulators in their respective working environments. The article points out that bankers and regulators find the trade-off between two social identities very difficult due to several reasons. As the article demonstrates, concerns for private gains within the banker or regulator identity and structural forces are very likely to shadow concerns for the implications for their social identities.

To overcome such challenges, the article briefly discussed three policy proposals to address the multiple identity problem. It is proposed in the article that in contexts where a single regulator cannot overcome the multiple identity problem by neglecting its public interestorientation due to various reasons, it is suggested to switch to a multiple regulatory structure where the central bank and the banking regulatory agency establish a check and balances system. Second, bail-in and bail-out resolution mechanisms are proposed to be part of the regulator's tools at the same time because each of them can address the multiple identity problem both bankers and regulators have. Having the two together may work better to make the two actors feel more ownership in the system and be accountable to the society. The article, similar to many others, cannot is left with many unaddressed questions. Future research may consider the effect of interactions with international actors (e.g. foreign banks, international organisations, etc.) on local actors to find a balance between multiple identities. Second and perhaps more challenging issue is to consider the possibility of fluidity of multiple identities. Individuals do have hundreds of identities, and for simplicity this article was only able to discuss two identities. Future research is needed, possibly with the help of behavioural economics, to enlighten us how individuals switch from one identity to other, or on how identity salience in the area of banking regulation works. These two more complicated questions have to be addressed in the future because the conception of taxpayer versus banker is too abstract and reductionist. We have to consider multiple identities and their implications on the way individuals make choices. 